\title{
The Role of Granulocyte-Colony Stimulating Factor (G-CSF) in the Healthy Brain: A Characterization of G-CSF-Deficient Mice
}

\author{
Kai Diederich, ${ }^{1 *}$ Sevgi Sevimli, ${ }^{1 *}$ Henrike Dörr, ${ }^{6}$ Evelin Kösters, ${ }^{3}$ Maike Hoppen, ${ }^{1}$ Lars Lewejohann, ${ }^{2}$ Rainer Klocke, ${ }^{4}$ \\ Jens Minnerup, ${ }^{1}$ Stefan Knecht, ${ }^{1}$ Sigrid Nikol, ${ }^{4}$ Norbert Sachser, ${ }^{2}$ Armin Schneider, ${ }^{7}$ Ali Gorji, ${ }^{3}$ Clemens Sommer, ${ }^{6 * *}$ \\ and Wolf-Rüdiger Schäbitz ${ }^{5 * *}$ \\ Department of ${ }^{1}$ Neurology and ${ }^{2}$ Behavioral Biology, and ${ }^{3}$ Institute of Physiology I, University of Muenster, ${ }^{4}$ Department of Cardiology and Angiology, \\ University Hospital of Muenster, and ${ }^{5}$ Department of Neurology, Evangelisches Krankenhaus Bielefeld and University of Muenster, 48149 Muenster, \\ Germany, ${ }^{6}$ Department of Neuropathology, University of Mainz, 55131 Mainz, Germany, and 7 Sygnis Bioscience, 69120 Heidelberg, Germany
}

Granulocyte-colony stimulating factor (G-CSF) is a hematopoietic growth factor that controls proliferation and differentiation of neural stem cells. Although recent studies have begun to explore G-CSF-related mechanisms of action in various disease models, little is known about its function in the healthy brain. In the present study, the effect of G-CSF deficiency on memory formation and motor skills was investigated. The impact of G-CSF deficiency on the structural integrity of the hippocampus was evaluated by analyzing the generation of doublecortin-expressing cells, the amount of bromodeoxyurine-labeled cells, the dendritic complexity in hippocampal neurons, the binding densities of NMDA and $\mathrm{GABA}_{\mathrm{A}}$ receptors and the induction of long-term potentiation (LTP). G-CSF deficiency caused a disruption in memory formation and in the development of motor skills. These impairments were associated with reduced ligand binding densities of NMDA receptors in hippocampal subfields $\mathrm{CA} 3$ and the dentate gyrus. The reduced excitation was potentiated by increased ligand binding densities of $\mathrm{GABA}_{\mathrm{A}}$ receptors resulting in a relative shift in favor of inhibition and impaired behavioral performance. These alterations were accompanied by impaired induction of LTP in the CA1 region. Moreover, G-CSF deficiency led to decreased dendritic complexity in hippocampal neurons in the dentate gyrus and the CA1 region. G-CSF deficiency also caused a reduction of neuronal precursor cells in the dentate gyrus. These findings confirm G-CSF as an essential neurotrophic factor, and point to a role in the proliferation, differentiation and functional integration of neural cells necessary for the structural and functional integrity of the hippocampal formation.

\section{Introduction}

Granulocyte-colony stimulating factor (G-CSF) is a growth factor that stimulates proliferation, differentiation, and survival of hematopoietic progenitor cells. Relatively novel is the perception that G-CSF is also a potent growth factor in the CNS, paralleling numerous basic cellular mechanisms in analogy to its function in the hematopoietic system (Schabitz and Schneider, 2007; Solaroglu et al., 2007). Recent studies have revealed that G-CSF and its receptor (G-CSFR) are present in the brain, suggesting an important role of this factor in neuroprotection and functional

Received Jan. 28, 2009; revised June 29, 2009; accepted July 23, 2009.

This work was supported by the Interdisciplinary Center of Clinical Research (Nik1/032/08), Muenster, Germany and the MAIFOR (Mainzer Forschungsförderungsprogramm) Program of the Medical Faculty of the University of Mainz, Germany. The technical assistance of Magdeleine Bousfia and Birgit Jaxy is gratefully acknowledged. We also thank Zoë R. Hunter for her helpful comments on this manuscript and Viviane Reijak for performing the BrdU stainings and analysis. A.S., C.S., and W.-R.S. are inventors on a patent application regarding the neuroprotective effect of G-CSF.

*K.D. and S.S. contributed equally to this work.

${ }^{*}$ C.S. and W.-R.S. share senior authorship.

Correspondence should be addressed to Kai Diederich, Universitätsklinikum Münster, Klinik und Poliklinik für Neurologie, Albert-Schweitzer-Strasse 33, 48149 Muenster, Germany. E-mail: kai.diederich@uni-muenster.de. DOI:10.1523/JNEUROSCI.0453-09.2009

Copyright $\odot 2009$ Society for Neuroscience ～0270-6474/09/2911572-10\$15.00/0 recovery (Schneider et al., 2005). The G-CSF ligand and receptor show a broad, predominantly neuronal expression throughout the rat brain, with particularly high expression in the CA3 region of the hippocampal formation and the subgranular zone and hilus of the dentate gyrus (Schneider et al., 2005). The expression pattern of G-CSF combined with its strong trophic activity indicate a prominent role of this growth factor in hippocampal function.

Numerous reports have described the efficacy of G-CSF in animal models of different neurological diseases including stroke (Schabitz et al., 2003; Schneider et al., 2005; KomineKobayashi et al., 2006; Solaroglu et al., 2006; Minnerup et al., 2008), Parkinson's disease (Cao et al., 2006; Meuer et al., 2006), and Alzheimer's disease (Tsai et al., 2007). These studies confirm G-CSF as a neurotrophic factor, and ascertained its role in neuroprotection and neuroregeneration relevant to the most prominent neurodegenerative diseases. Although, recent studies have begun to explore G-CSF-related mechanisms of action in various disease models, little is known about its function in the healthy brain. A more detailed understanding of the physiological role of G-CSF in the healthy brain may, however, open new insights into disease relevant mechanisms. In the present study, we therefore 
performed several cognitive and sensomotoric tests to explore the effect of G-CSF deficiency on learning and memory formation and motor skills. Subsequently, we examined the impact of G-CSF deficiency on hippocampal neurogenesis and on dendritic complexity in hippocampal neurons. Binding densities of NMDA and $\mathrm{GABA}_{\mathrm{A}}$ receptors were examined using quantitative analysis of radioactivity performed in the cortical areas $\mathrm{M} 1, \mathrm{~S} 1$ and $\mathrm{S} 2$, the caudate-putamen and in the hippocampal subfields CA1, CA3, and the dentate gyrus. Additional electrophysiological recordings were performed to investigate the induction of long-term potentiation (LTP) in the CA1 region of hippocampal formation.

\section{Materials and Methods}

Animals

A total of $59 \mathrm{G}^{-C S S F^{-/-}}$, 59 wild-type, and $3 \mathrm{G}^{-\mathrm{CSF}^{+/-}}$mice (male; 3 months of age) were used in these experiments. G-CSF${ }^{-1-}$ mice were generated by targeted disruption of the G-CSF gene in embryonal stem

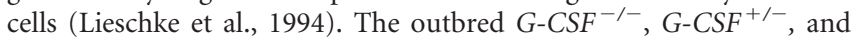
wild-type mice were derived from C57BL/6 and 129 inbred strains. They were housed in groups of two animals in Macrolon cages. All mice were kept under controlled environmental conditions (ambient temperature $22^{\circ} \mathrm{C}, 12 \mathrm{~h}$ light/dark cycle, lights on at 7:00 A.M.). Tap water and food was allowed ad libitum. Two weeks before behavioral testing mice were handled daily by the experimenter. All behavioral testing was performed during the mice light cycle between 8:00 A.M. and 1:00 P.M. All experiments were done in accordance with the European Communities Council Directive of 24 November 1986 (86/609/EEC). All efforts were made to minimize the number of animals used and their suffering.

\section{Behavioral testing}

Skilled motor learning. Fifteen $\mathrm{G}-\mathrm{CSF}^{-/-}$and 14 wild-type animals were used in this experiment. A rotarod with a $7 \mathrm{~cm}$ diameter rod and acceleration capability (TSE Systems) was used to assess skilled motor learning. Before the daily training mice were allowed to accommodate on the rod for $5 \mathrm{~min}$. For each session mice were subjected to 10 rotarod trials. Constant accelerating speed from 4 to $50 \mathrm{rpm}$ for $300 \mathrm{~s}$ was used until the mouse fell from the rod and activated a light sensor, which stopped rotation. Time was recorded when an animal fell off or made two consecutive revolutions, holding onto the rod. The time interval between trials was $30 \mathrm{~s}$.

Water maze. Ten G-CSF${ }^{-1-}$ and 10 wild-type mice were used in this experiment. A Morris water maze task was used to assess spatial memory performance. The pool had a diameter of $1.50 \mathrm{~m}$ and was filled with opaque water; the water temperature was maintained at $21^{\circ} \mathrm{C}$.

Before the spatial training a habituation trial was performed. During a habituation trial the animals had to swim for $60 \mathrm{~s}$ with no platform placed in the pool.

The following $2 \mathrm{~d}$, a nonspatial guided performance was assessed by performing four cued training trials each day in which a visible platform $2 \mathrm{~cm}$ above the surface of the water was presented. The location of the platform varied randomly among the quadrants of the pool from trial to trial. On each trial, the mouse was allowed $30 \mathrm{~s}$ to reach the platform and then allowed to remain there briefly before being returned to a holding cage for $60 \mathrm{~s}$ before the beginning of the next trial.

For the assessment of spatial memory performance the mice learned to use spatial cues in the room to navigate to the escape platform positioned at a fixed location below the water surface. The mice were released into the pool from randomly varying positions for a maximum trial duration of $90 \mathrm{~s}$. On each of the 8 acquisition days each animal performed four trials, with an intertrial interval of $60 \mathrm{~s}$. The probe trial (90 s) was performed on the 9th $\mathrm{d}$ with the platform removed from the pool. All trials were recorded with a video camera connected to a computer equipped with the Ethovision XT tracking software (Noldus).

Open field. Twelve $\mathrm{G}_{-} \mathrm{CSF}^{-1-}$ and 13 wild-type animals were used in this experiment. Locomotor activity and the ratio between exploration and fear of open space, as measured by the time spent near the walls or in the center of the arena, were assessed using an open field. At the beginning of the test sessions, each mouse was placed in the middle of the open field, an $80 \mathrm{~cm} \times 80 \mathrm{~cm}$ square arena with $40 \mathrm{~cm}$ high walls. The time spent in different areas of the open field (center, wall, corner) and the total distance traveled (meters) were recorded by an automated tracking system (http://www.phenotyping.com/digital.html). After 10 min mice were released from the test chamber. Open field tests were performed on 3 consecutive days.

Object recognition test. Twenty-four hours after the open field exploration, the same $12 \mathrm{G}-\mathrm{CSF}^{-1-}$ and 13 wild-type animals were trained and tested in a novel object recognition task. Training in the object recognition task took place in the same arena used for the open field exploration. The open field exploration was thus used as a context habituation trial for the recognition memory task. The training was conducted by placing individual mice into the arena, $9 \mathrm{~cm}$ from the walls. In the arena two identical objects (objects A1 and A2) were positioned in two adjacent corners. Animals were left to explore the objects for $10 \mathrm{~min}$. In a shortterm memory test given with a delay of $1 \mathrm{~h}$ after training, the mice were exposed to one familiar (A) and one novel (B) object for $10 \mathrm{~min}$.

On the subsequent day a long-term memory test was performed by exposing the same mice to two identical objects (objects $\mathrm{C} 1$ and $\mathrm{C} 2$ ) different to the already familiar ones. After a delay of $24 \mathrm{~h}$, the mice explored the arena for $10 \mathrm{~min}$ in the presence of the familiar object $\mathrm{C}$ and a novel object D. Sniffing, dragging, pushing, and gnawing of the objects was recorded. The time the animals spent on these behaviors (investigating time) was taken as a measure of object recognition. All objects had similar textures, colors, and sizes, but distinctive shapes. Between trials the objects were washed with $10 \%$ ethanol solution. A recognition index calculated for each animal was expressed by the ratio $T_{\mathrm{NO}} /\left(T_{\mathrm{FO}}+T_{\mathrm{NO}}\right)$ $\left[T_{\mathrm{FO}}=\right.$ time spent exploring the familiar object; $T_{\mathrm{NO}}=$ time spent exploring the novel object].

Elevated-plus-maze. The same $12 \mathrm{G}_{-} \mathrm{CSF}^{-/-}$and 13 wild-type animals that underwent the open field and the object recognition test were used in this experiment. Anxiety-related behavior was measured by means of the elevated plus-maze on which mice had the choice to move into opposing arms, which were either shielded or open. Preference for open arms is thought to reflect exploration and preference for shielded arms is thought to indicate anxiety. The maze was elevated $50 \mathrm{~cm}$ above floor level, with $30 \mathrm{~cm}$ long and $5 \mathrm{~cm}$ wide arms. At the beginning of each experiment, mice were placed into the center of the maze randomly facing one of the arms. Each entry into an open or shielded arm was counted and the time animals spent in either type of arm was measured over a period of $10 \mathrm{~min}$.

\section{Bromodeoxyuridine staining}

The brains of $5 \mathrm{G}-\mathrm{CSF}^{-1-}$ and 5 wild-type mice were used in this part of the experiment. For the purpose of labeling newborn cells each mouse received a daily bromodeoxyuridine (BrdU) injection $(30 \mathrm{mg} / \mathrm{kg} / \mathrm{d}$, i.p.) for $5 \mathrm{~d}$. Mice were perfused $6 \mathrm{~d}$ after the final BrdU injection. Animals were deeply anesthetized using a mixture of ketamine $(20.38 \mathrm{mg} / \mathrm{ml})$ and xylazine $(5.38 \mathrm{mg} / \mathrm{ml})$. Transcardiac perfusion was performed with $0.9 \%$ $\mathrm{NaCl}$ solution. Brains were removed and postfixed in paraformaldehyde solution for $4 \mathrm{~d}$ at $4^{\circ} \mathrm{C}$. The tissue was then cryoprotected via $24 \mathrm{~h} \mathrm{im-}$ mersion in $30 \%$ sucrose, PBS solution. Brains were cut into $40 \mu \mathrm{m}$ sagittal sections using a sliding microtome on dry ice. Free-floating sections were treated with $0.6 \% \mathrm{H}_{2} \mathrm{O}_{2}$ in Tris-buffered saline (TBS; $0.15 \mathrm{M} \mathrm{NaCl}$, $0.1 \mathrm{~m}$ Tris- $\mathrm{HCl}, \mathrm{pH} 7.5$ ) for $30 \mathrm{~min}$. After extensive washes in TBS, sections were blocked with a solution containing TBS, $0.1 \%$ Triton X-100 and $3 \%$ normal donkey serum solution for $30 \mathrm{~min}$. The same solution was used during the incubation with antibodies. Primary antibodies were applied overnight at $4^{\circ} \mathrm{C}$. For epifluorescence immunodetection, sections were washed extensively and incubated with fluorochromeconjugated species-specific secondary antibodies. Sections were placed on Superfrost Plus slides (Menzel-Gläser) and mounted in Prolong Antifade kit (Invitrogen). The following antibodies were used: rat anti-BrdU (1:500, Accurrate), mouse anti-NeuN (1:500, Millipore Bioscience Research Reagents).

To determine the number of BrdU-positive cells in the hippocampus, every sixth section ( $240 \mu \mathrm{m}$ intervals) of one cerebral hemisphere was selected from each animal and processed for immunohistochemistry. Because BrdU-labeled cells are comparatively rare in the dentate gyrus, 
all BrdU-positive cells in the granule cell layer of the hippocampal dentate gyrus were exhaustively counted using a Nikon Eclipse 80i microscope. The amount of cells counted was then extrapolated to receive an approximated value for the whole brain. To determine the percentage of neuronal differentiation of the newly generated cells 50 BrdU-positive cells within the granule cell layer were randomly selected and analyzed for $\mathrm{BrdU} / \mathrm{NeuN}$ double-labeling. The resulting percentages of NeuNpositive cells among the BrdU-positive cells were multiplied with the estimated number of BrdU-positive cells to estimate the number of newly generated neurons.

\section{Doublecortin staining}

The brains of six $G-C S F^{-1-}$ and six wild-type mice were used in this part of the experiment. Animals were deeply anesthetized using a mixture of ketamine $(20.38 \mathrm{mg} / \mathrm{ml})$ and xylazine $(5.38 \mathrm{mg} / \mathrm{ml})$. Transcardiac perfusion was performed with $0.9 \% \mathrm{NaCl}$ solution. Brains were removed and postfixed in paraformaldehyde solution for $4 \mathrm{~d}$ at $4^{\circ} \mathrm{C}$. The tissue was then cryoprotected via $24 \mathrm{~h}$ immersion in $30 \%$ sucrose, PBS solution. Brains were cut into $40 \mu \mathrm{m}$ sagittal sections using a sliding microtome on dry ice. Free-floating sections were treated with $0.6 \% \mathrm{H}_{2} \mathrm{O}_{2}$ in Trisbuffered saline (TBS; $0.15 \mathrm{M} \mathrm{NaCl}, 0.1 \mathrm{M}$ Tris- $\mathrm{HCl}, \mathrm{pH}$ 7.5) for $30 \mathrm{~min}$. After extensive washes in TBS, sections were blocked with a solution containing TBS, $0.1 \%$ Triton X-100 and 3\% normal donkey serum solution for $30 \mathrm{~min}$. The same solution was used during the incubation with antibodies. Primary antibodies were applied overnight at $4^{\circ} \mathrm{C}$. Sections were then washed extensively and incubated with species-specific secondary antibodies. Sections were placed on Superfrost Plus slides (Menzel-Gläser) and mounted in Prolong Antifade kit (Invitrogen). The goat anti-doublecortin (DCX) C-18 (1:500, Santa Cruz Biotechnology) antibody was used.

To determine the number of DCX-positive cells in the hippocampus, every sixth section ( $240 \mu \mathrm{m}$ intervals) of one cerebral hemisphere was selected from each animal and processed for immunohistochemistry. All DCX-positive cells in the granule cell layer of the hippocampal dentate gyrus were manually counted using a Nikon Eclipse $80 \mathrm{i}$ microscope. The amount of cells counted was then extrapolated to receive an approximated value for the whole brain.

\section{Golgi-Cox staining and morphological analysis of neurons}

The brains of five $\mathrm{G}_{-} \mathrm{CSF}^{-/-}$and five wild-type mice were used in this part of the experiment. Mice were transcardially perfused with $0.9 \%$ saline, the brains were removed and placed each in $20 \mathrm{ml}$ of Golgi-Cox solution (Gibb and Kolb, 1998) according to a modified protocol of Eadie et al. (2005). Briefly, brains were stored in the dark at room temperature for $14 \mathrm{~d}$. Afterward they were placed in a $20 \%$ sucrose solution and stored in the dark at $4^{\circ} \mathrm{C}$ for another $2 \mathrm{~d}$. Then, they were cut on a vibratome in $200-\mu \mathrm{m}$-thick coronal slices. Sections were mounted on TESPA-coated (Merck) slides and treated with the following solutions: $\mathrm{H}_{2} \mathrm{O}$ (1 min), ammonium hydroxide (30 min, in the dark), $\mathrm{H}_{2} \mathrm{O}$ (1 min), Agfafix for film (30 min), $\mathrm{H}_{2} \mathrm{O}(1 \mathrm{~min})$ followed by dehydration in ascending alcohol concentrations. After processing, all slides were coverslipped using Cytoseal XYL (Richard-Allan Scientific) and stored in a cool, dry place and kept from light exposure.

Golgi-impregnated neurons from two regions of the brain (hippocampal CA1 and hippocampal dentate gyrus) were examined. Four neurons from each area were selected and traced using the Neurolucida Image Analyses System (Microbrightfield). The total dendritic length and the amount of dendritic branch points (nodes) were calculated and used for statistical comparison.

\section{Receptor autoradiography}

The brains of seven $G$ - $C S F^{-1-}$ and seven wild-type mice were used for receptor autoradiography. Before this experiment these animals were also used in the open field, object recognition test and elevated-plusmaze. The tissue used for receptor autoradiography was taken from decapitated animals without perfusion. Brains were rapidly removed, frozen in isopentane at $-30^{\circ} \mathrm{C}$ for $10 \mathrm{~min}$, and stored at $-80^{\circ} \mathrm{C}$ until analysis. Quantitative in vitro receptor autoradiography studies were performed using $\left[{ }^{3} \mathrm{H}\right] \mathrm{MK}-801$ and $\left[{ }^{3} \mathrm{H}\right]$ muscimol as ligands for NMDA and $\mathrm{GABA}_{\mathrm{A}}$ receptors, respectively. Ligands were purchased from
Perkin-Elmer. Labeling of and incubation procedures for the different binding sites were performed according to protocols of Zilles et al. (2000). In brief, incubation with $\left[{ }^{3} \mathrm{H}\right] \mathrm{MK}-801$ and $\left[{ }^{3} \mathrm{H}\right]$ muscimol was always preceded by a preincubation period with the respective buffer to remove endogenous ligands. To demonstrate the maximal binding of $\left[{ }^{3} \mathrm{H}\right] \mathrm{MK}-801$ to NMDA receptors, the binding assay was performed in a magnesium- and zinc-free solution ( $50 \mathrm{~mm}$ Tris- $\mathrm{HCl}$ buffer, $\mathrm{pH}$ 7.2) and in the presence of $30 \mu \mathrm{M}$ glycine and $50 \mu \mathrm{M}$ spermidine with $5 \mathrm{nM}$ $\left[{ }^{3} \mathrm{H}\right] \mathrm{MK}-801$ (specific activity $22.0 \mathrm{Ci} / \mathrm{mmol}$ ) at $22^{\circ} \mathrm{C}$ for $60 \mathrm{~min}$. Incubation was terminated by washing in cold buffer $(2 \times 5 \mathrm{~min})$ and in $\mathrm{H}_{2} \mathrm{O}$ (2 s). GABA receptors were incubated with $3 \mathrm{~nm}\left[{ }^{3} \mathrm{H}\right]$ muscimol (specific activity $20.0 \mathrm{Ci} / \mathrm{mmol}$ ) in a $50 \mathrm{~mm}$ Tris-citrate buffer, $\mathrm{pH} 7.0$, for 40 $\min$ at $4^{\circ} \mathrm{C}$. Incubation was terminated by rinsing $(3 \times 4 \mathrm{~s})$ in cold buffer. After the final rinsing procedure, slides were carefully dried in a stream of cool air. Air-dried, tritium-labeled sections were coexposed with ${ }^{3} \mathrm{H}-$ labeled plastic standards (Autoradiographic $\left[{ }^{3} \mathrm{H}\right]$ Microscales; GE Healthcare) to a ${ }^{3} \mathrm{H}$-sensitive film (Hyperfilm- ${ }^{3} \mathrm{H}$; GE Healthcare) for 5 weeks. Autoradiographies were scanned in equal light conditions with a digital camera (Roper Scientific) and digitized with the MCID image analysis system (Imaging Research Inc.). Gray value images of the coexposed plastic standards were used to compute a nonlinear calibration curve, which defined the relationship between gray values in the autoradiographs and concentrations of radioactivity. Quantitative analysis of radioactivity was performed in cortical areas M1, S1 and S2, caudateputamen and in hippocampal subfields CA1 and CA3 within the dendritic strata oriens and radiatum, as well as in the pyramidal cell layer. In the DG, ligand binding was analyzed in the stratum moleculare and in the granule cell layer. Regions of interest were marked on the monitor and the gray values automatically assessed by the imaging software. In all cases, nonspecific binding was just above background labeling or not visible at all. Therefore, background density could be used as an estimate of unspecific binding and subtracted from total binding.

\section{Electrophysiological recordings and LTP}

The brains of six $\mathrm{G}_{-} \mathrm{CSF}^{-/-}$, three $\mathrm{G}-\mathrm{CSF}^{+/-}$, and six wild-type mice were used for electrophysiological recordings. Mice were decapitated under deep isofluran anesthesia and the brains were rapidly removed to ice-cold $\left(4^{\circ} \mathrm{C}\right)$ artificial CSF (ACSF). The cerebellum was removed and a cut was made to divide the two cerebral hemispheres. Combined amygdala-hippocampus-cortex slices containing the temporal cortex, the perirhinal cortex, the entorhinal cortex, the subiculum, the dentate gyrus, the hippocampus, as well as the amygdala $(500 \mu \mathrm{m})$ were cut in a nearly horizontal plane. Up to two different slices from each side were collected in a preparation. Slices were stored at $28^{\circ} \mathrm{C}$ in ACSF, which contained (in mM) $124 \mathrm{NaCl}, 4 \mathrm{KCl}, 1.0 \mathrm{CaCl}_{2}, 1.24 \mathrm{NaH}_{2} \mathrm{PO}_{4}, 1.3$ $\mathrm{MgSO}_{4}, 26 \mathrm{NaHCO}_{3}, 10$ glucose, $\mathrm{pH} 7.4$, oxygenated with $95 \% \mathrm{O}_{2}$ and $5 \% \mathrm{CO}_{2}$ for $>1 \mathrm{~h}$. After $30 \mathrm{~min}$ incubation, $\mathrm{CaCl}_{2}$ was elevated to 2.0 $\mathrm{mmol} / \mathrm{L}$. Slices were individually transferred to an interphase recording chamber, placed on a transparent membrane, illuminated from below and continuously perfused $(1.5-2 \mathrm{ml} / \mathrm{min})$ with carbogenated ACSF at $32^{\circ} \mathrm{C}$. A warmed, humified $95 \% \mathrm{O}_{2}$ and $5 \% \mathrm{CO}_{2}$ gas mixture was directed over the surface of the slices.

Extracellular field potentials were recorded with glass microelectrodes (150 mmol/L NaCl; 2-10 M 2 ) connected to the amplifier by an Ag/ $\mathrm{AgCl}-\mathrm{KCl}$ bridge in the hippocampal CA1 (stratum pyramidale). Single electrical stimuli $(0.05 \mathrm{~Hz})$ were delivered through a bipolar platinum electrode to stimulate the Schaffer collaterals of hippocampal slices. The evoked field EPSPs (fEPSP) were elicited by adjusting the intensity of stimulation to $40 \%$ of the maximum response in CA1 area. In LTP experiments, CA1 area was sequentially stimulated once every minute. Tetanic stimulations were applied when the amplitude of fEPSP remained stable with a maximum difference of $10 \%$ for at least $30 \mathrm{~min}$.

LTP was elicited by either 10 trains of four pulses (pulse duration 0.1 $\mathrm{ms}$; interpulse interval $50 \mathrm{~ms}$ ) repeated at intervals of $10 \mathrm{~s}$ or four trains of $100 \mathrm{~Hz}(1 \mathrm{~s})$ repeated at intervals of $5 \mathrm{~min}$ as well as by a single $1 \mathrm{~s}$ train at $100 \mathrm{~Hz}$ stimulation. LTP was operationally defined as the mean change in fEPSP slope for 15 intensity stimuli given beginning $30 \mathrm{~min}$ after tetanic stimulation compared with the mean slope of 15 test pulses given imme- 

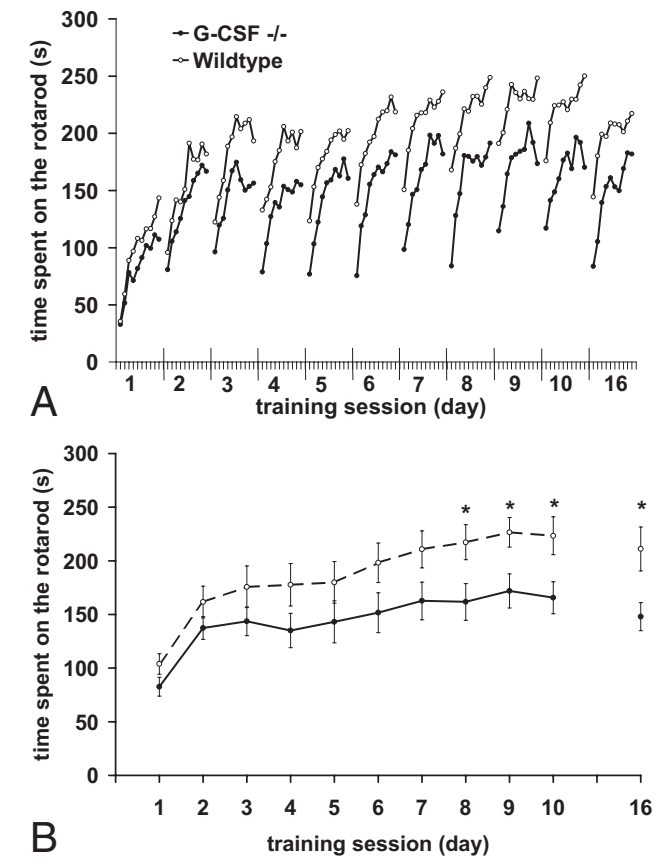

Figure 1. Effect of a G-CSF deficit on skilled motor learning. Rotarod performance within $(\boldsymbol{A})$ and between sessions $(\boldsymbol{B})$ are shown (10 trials per session, average performance is displayed for each session). Asterisks symbolize a statistically significant difference ( $p<0.05$; Bonferroni corrected post hoc test after significant ANOVA). G-CSF-deficient mice showed reduced motor skill learning resulting in a parallel-shift of intra- and intersession learning curves to a worse level of performance.

diately before the stimulation. Thus, percentage potentiation $=100$ (post-tetanus amplitude/baseline amplitude).

\section{Statistical analysis}

All analyses were performed with the statistical software SPSS (version 15.00 for Windows). Two-way repeated measures ANOVA was used when data of different groups was repeatedly collected over time or under different treatment conditions. Student's $t$ tests or Mann-Whitney rank sum tests were calculated to compare data between two groups. All tests were performed two-tailed and a value of $p<0.05$ was considered to represent a significant difference. The results of the receptor autoradiography were analyzed using an ANOVA for comparison of postmortem wild-type and $G-C S F^{-1-}$ mouse brains. Ligand binding was analyzed by calculating mean concentration values for each ligand and region. Final values were normalized to wild-type mice (100\%) and expressed as mean \pm SEM as described previously (Schomacher et al., 2006). Significant group effects between different groups were confirmed by ANOVA and Bonferroni error protection.

\section{Results}

\section{Effects of G-CSF deficiency on memory formation and} anxiety-related behavior

Skilled motor learning

$G-C S F^{-1-}$ and wild-type mice showed overall improved rotarod performance within sessions (Fig. $1 A$ ) and between sessions (Fig. $1 B)$. Whereas baseline performance between the first two trials was comparable (see Fig. 1A), G-CSF-deficient mice showed reduced motor skill learning during the subsequent trials resulting in a parallel shift of intra- and intersession learning curves to significantly worse performance levels. A repeated measures ANOVA revealed significant effects of group $\left(F_{(1,24)}=4.848 ; p<\right.$ $0.05)$ and trial $\left(F_{(1,24)}=56.735 ; p<0.001\right)$, but no group by trial interaction $(p>0.05)$ for the intersession learning curves, as well as significant effects of group $\left(F_{(1,24)}=5.437 ; p<0.05\right)$ and trial $\left(F_{(1,24)}=65.278 ; p<0.001\right)$, but no group by trial interaction

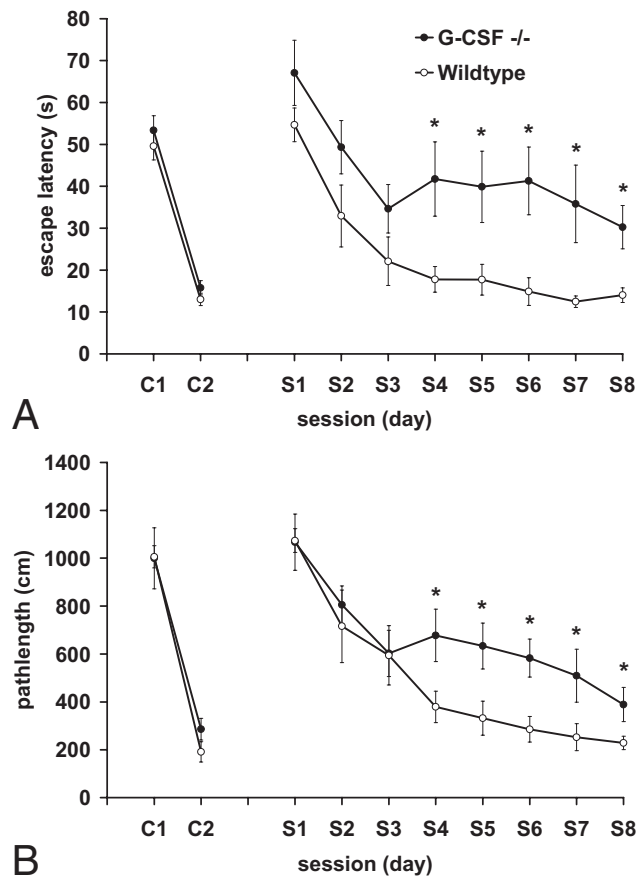

Figure 2. Effects of G-CSF deficiency on spatial memory formation in the Morris water maze task. $A$, The cued version of the water maze test revealed no effect of genotype on the escape latency ( $\left(1-C 2 ; p>0.05 ;\right.$ ANOVA). The escape latency of $\mathrm{G}-\mathrm{CSF}^{-1-}$ mice was significantly increased over the spatial learning trials compared with wild-type mice (S1-S8; $p<0.05$; ANOVA). All animals learned the task during the acquisition phase. $\boldsymbol{B}$ shows the length of the swim path to the platform. No effect of genotype on the pathlength was observed in the cued version of the water maze test ( $p>0.05$; ANOVA). During the spatial learning trials $\mathrm{G}_{-} \mathrm{CSF}^{-1-}$ mice took significantly longer paths to find the platform than the wild-type mice $(S 1-S 8 ; p<$ 0.05 ; ANOVA). Asterisks symbolize a statistically significant difference $(p<0.05$; Bonferroni corrected post hoc test after significant ANOVA). G-CSF ${ }^{-1-}$ mice exhibited impaired spatial memory formation during the probe trial ( $90 \mathrm{~s}$ total duration), displaying longer latencies to reach the platform area (mean G-CSF${ }^{-1-}: 35 \mathrm{~s} \pm 11.56 \mathrm{SEM}$; mean wild type: $8.2 \pm 1.44 ; p<$ 0.05 ; Student's $t$ test), less time spent in the target quadrant (mean $\mathrm{CCSF}^{-/-}: 36.83 \mathrm{~s} \pm 7.72$ SEM; mean wild type: $54.03 \pm 4.05 ; p<0.05$; Student's $t$ test), and a lesser amount of platform crossings compared with wild-type mice (mean $\mathrm{G}-\mathrm{CSF}^{-1-}: 4.56 \pm 1.12 \mathrm{SEM}$; mean wild type: $8.1 \pm 1.44 ; p<0.05 ;$ Student's $t$ test).

$(p>0.05)$ for the intrasession learning curves. Post hoc tests with Bonferroni correction showed significantly reduced amount of time spent on the rotarod starting on session 8 until session 16 $(p<0.05)$.

Morris water maze

The cued version of the water maze test revealed no betweengroup differences in escape latency (repeated measures ANOVA; $\left.F_{(1,18)}=1.638 ; p>0.05\right)$. Performance improved during the course of cued training $\left(F_{(1,18)}=189.549 ; p<0.001\right)$ without an interaction between genotype and time $(p>0.05)$. No effect of genotype on the distance moved or on swimming speed was found (distance moved, $F_{(1,18)}=0.317 ; p>0.05$ ) (swimming speed, $\left.F_{(1,18)}=0.561 ; p>0.05\right)$

During the spatial learning trials, the latency for finding the hidden platform was significantly longer for G-CSF-deficient mice than for wild-type mice (repeated measures ANOVA; $F_{(1,18)}=10.017 ; p<0.01$ ) (Fig. 2). The analysis of the path length (which is less influenced by motivational bias and lack of bodily fitness) revealed longer search paths for $G-C S F^{-1-}$ mice than for wild-type mice across the whole acquisition period (repeated measures ANOVA; $\left.F_{(1,18)}=5.208 ; p<0.05\right)$. Post hoc tests with Bonferroni correction showed significantly longer search 

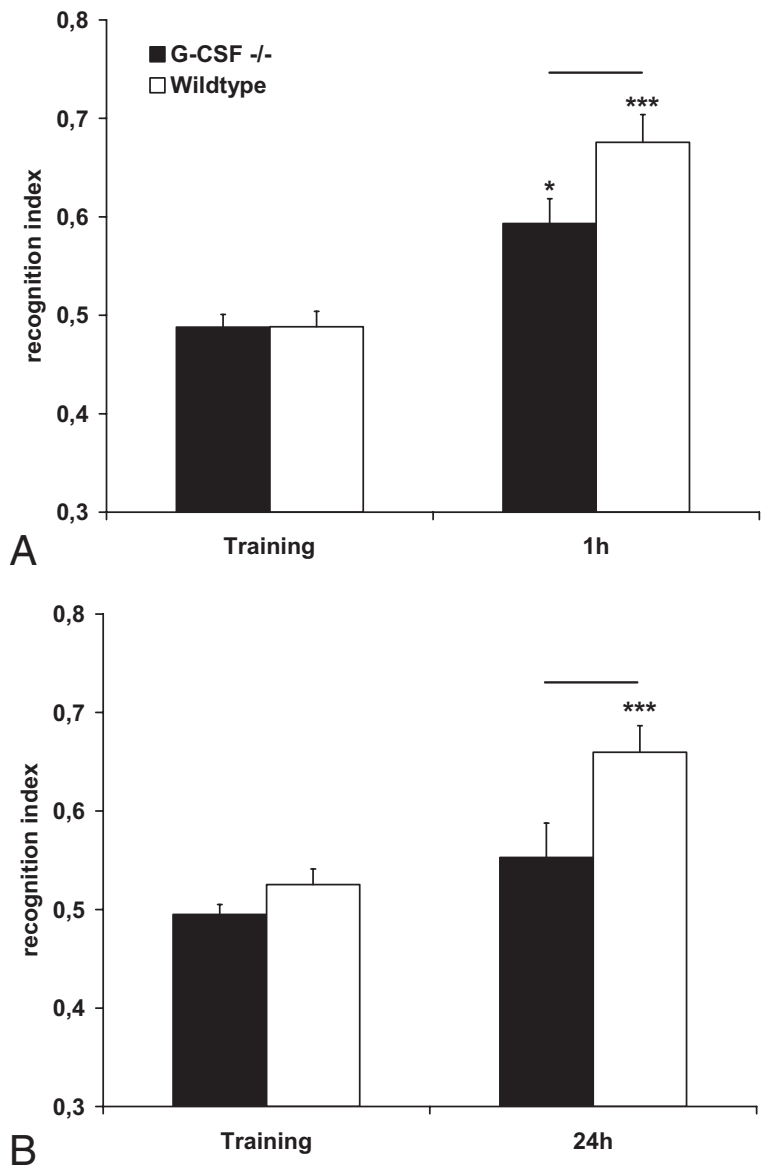

Figure 3. Effect of a G-CSF deficit on recognition memory. The short-term retention test was performed $1 \mathrm{~h}$ after training $(\boldsymbol{A})$ and a long-term retention test $24 \mathrm{~h}$ after training $(\boldsymbol{B})$. The recognition index calculated for each animal was expressed by the ratio $T_{\mathrm{NO}} /\left(T_{\mathrm{FO}}+T_{\mathrm{NO}}\right)\left[T_{\mathrm{FO}}=\right.$ time spent exploring the familiar object; $T_{\mathrm{NO}}=$ time spent exploring the novel object]. Significant changes between training and test condition are indicated by asterisks $\left({ }^{*} p<0.05 ;{ }^{* *} p<\right.$ $\left.0.01 ;{ }^{* * *} p<0.001\right)$, significant differences between ${\mathrm{G}-\mathrm{CSF}^{-\prime-}}^{-}$and wild-type mice are indicated by horizontal bars $(p<0.05)$.

paths and longer latencies to reach the platform starting on session 4 until session $8(p<0.05)$. No significant effect of G-CSF deficiency on the swimming speed was found during the spatial learning trials (repeated measures ANOVA; group, trial and group trial interaction, $p>0.05$, data not shown). A probe trial, during which the platform was removed from the pool, was performed on the ninth training trial of the acquisition period. T-tests revealed an effect of G-CSF deficiency on time spent in the target quadrant (mean $G-C F^{-/-}: 36.83 \mathrm{~s} \pm$ 7.72 SEM; mean wild type: $54.03 \pm 4.05 ; p<0.05$; Student's $t$ test), on the latency to reach the target area (mean $G-C S F^{-/-}$: $35 \mathrm{~s} \pm 11.56 \mathrm{SEM}$; mean wild type: $8.2 \pm 1.44 ; p<0.05$; Student's $t$ test) and on entries into the target area (mean $G-C S F^{-/-}: 4.56 \pm 1.12$ SEM; mean wild type: $8.1 \pm 1.44 ; p<$ 0.05 ; Student's $t$ test).

\section{Object recognition test}

Figure 3 shows the effect of a G-CSF deficit on object recognition memory. There was no significant difference between groups for the training trials ( $p>0.05$; Student's $t$ test). G-CSF ${ }^{-/-}$mice showed significantly reduced short term recognition memory compared with wild-type mice ( $p>0.05$; Student's $t$ test). However, a significant difference between training and test condition within the $G-C S F^{-/-}$group points to a partly preserved ability to distinguish between familiar and novel objects after a $1 \mathrm{~h}$ intertrial interval ( $p<0.05$; Student's $t$ test).

The long-term retention trial revealed an impaired long-term memory in G-CSF-deficient mice. G-CSF${ }^{-/-}$mice were unable to differentiate between the objects after a $24 \mathrm{~h}$ interval, as confirmed by similar recognition indices in the training and retention trials $(p>0.05$; Student's $t$ test) (Fig. $3 B)$.

\section{Open field}

In the open field, G-CSF-deficient mice did not show any significant alterations in locomotor activity or anxiety-related behavior compared with wild-type mice. Animals of both groups showed comparable amounts of locomotor activity as measured by the distance traveled (repeated measures ANOVA; group, trial and group trial interaction; $p>0.05$; data not shown). The proportion of time spent in the middle of the arena vs time spent in other areas serves as a tentative measure of anxiety. A comparison between $\mathrm{G}_{-} \mathrm{CSF}^{-1-}$ and wild-type mice did not reveal a significant difference (repeated measures ANOVA; group, trial and group trial interaction; $p>0.05$; data not shown). This result was verified by an elevated-plus-maze test.

\section{Elevated-plus-maze}

In the elevated-plus-maze test, G-CSF-deficient mice did not show any significant alterations in anxiety-related behavior compared with wild-type mice. Both $G-C S F^{-/-}$and wild-type mice explored the apparatus to a considerable amount measured by total arm entries (mean $G-C S F^{-1-}: 21 \pm 2.25$ SEM; mean wildtype: $18 \pm 2.05$ ). The proportion of open arm vs total arm entries $\left(G-C S F^{-/-}: 22.12 \% \pm 5.86\right.$ SEM; wild-type: $\left.22.73 \pm 3.33\right)$ and the proportion of time spent in the open arm vs total time spent on the maze (G-CSF${ }^{-/-}: 12.06 \% \pm 3.62$ SEM; wild-type: $9.61 \pm$ 2.52) serves as a measure of anxiety. A comparison between $G-C S F^{-/-}$and wild-type mice did not reveal a significant difference in these measures of anxiety-related behavior $(p>0.05$; Student's $t$ test).

\section{Quantification of BrdU/NeuN-positive cells}

To assess whether G-CSF deficiency led to an altered generation of newborn neurons, BrdU/NeuN-positive cells were quantified in the dentate gyrus. G-CSF deficiency led to a significant decrease in the amount of BrdU/NeuN-positive cells in the dentate gyrus (mean $G$-CSF ${ }^{-/-}: 1634.11 \pm 189.56$ SEM; mean wild type: $5690.69 \pm 319.77 ; p<0.001$; Student's $t$ test) (Fig. $4 A$ ). Furthermore, a Student's $t$ test revealed a significant decrease in the total amount of BrdU-positive cells in the dentate gyrus of G-CSFdeficient animals compared with their wild type littermates (mean G-CSF ${ }^{-/-}: 1944 \pm 253.31$ SEM; mean wild type: $6873 \pm$ 433.09; $p<0.001$ ). To estimate the number of newly generated neurons within the dentate gyrus, the number of cells-positive for both BrdU and NeuN was divided by the cells-positive for BrdU times 100. G-CSF deficiency exerted no significant neuronspecific effects (mean $G-C S F^{-1-}: 85.2 \pm 1.15$ SEM; mean wild type: $84.4 \pm 1.22 ; p>0.05$; Student's $t$ test).

\section{Quantification of doublecortin-expressing cells}

To determine the effect of G-CSF deficiency on the generation of neuronal precursors, the amount of DCX-expressing cells in the dentate gyrus was assessed. G-CSF deficiency caused a significant reduction in the amount of DCX-expressing cells in the dentate gyrus compared with wild-type mice (mean G-CSF${ }^{-1-}: 8004 \pm$ 3011.07 SEM; mean wild type: $34,752 \pm 11,317.28 ; p<0.05$; Student's $t$ test) (Fig. $4 B$ ). 

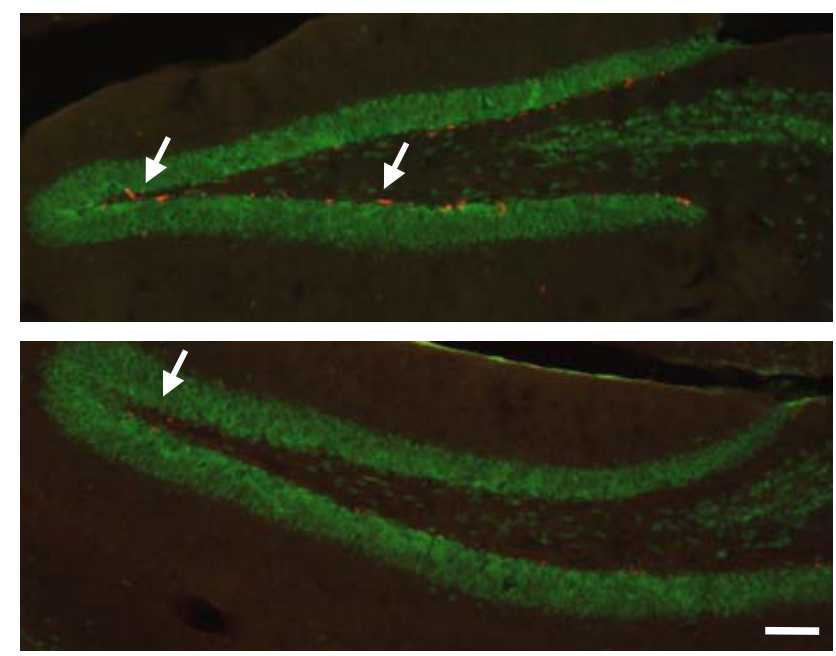

A

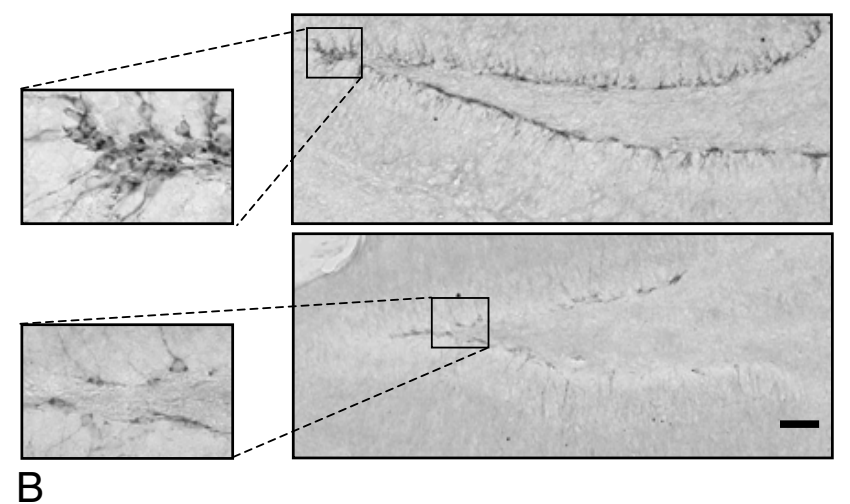

Figure 4. Quantification of neurogenesis by the detection of BrdU/NeuN- and DCXexpressing cells. $\boldsymbol{A}$, Immunodetection of BrdU in the dentate gyrus of wild-type mice (upper micrograph) and G-CSF ${ }^{-1-}$ mice (lower micrograph). G-CSF deficiency led to a significant reduction in the total amount of BrdU-positive cells (mean $\mathrm{G}^{-C S F}{ }^{-/-}, 1944 \pm 253.31$ SEM; mean wild type, $6873 \pm 433.09 ; p<0.001$, Student's $t$ test) and BrdU/NeuN-positive cells (mean G-CSF ${ }^{-1-}, 1634.11 \pm 189.56$ SEM; mean wild type, $5690.69 \pm 319.77 ; p<0.001$, Student's $t$ test). Scale bar, $80 \mu \mathrm{m}$. $\boldsymbol{B}$, Immunodetection of DCX in the dentate gyrus of wildtype mice (upper micrograph) and G-CSF ${ }^{-1-}$ mice (lower micrograph). G-CSF deficiency led to a significant reduction in the amount of $D C X$-expressing cells compared with wild-type mice (mean G-CSF ${ }^{-1-}, 8004 \pm 3011.07$ SEM; mean wild type, 34,752 $\pm 11,317.28 ; p<0.05$, Student's $t$ test). Scale bar, $80 \mu \mathrm{m}$

\section{Morphological analysis of neurons}

To examine the effect of G-CSF deficiency on dendritic complexity in hippocampal neurons, the total dendritic length and the amount of dendritic branch points (nodes) were calculated from traced neurons in the CA1 region (Fig. $5 A, B$ ) and dentate gyrus. The lack of G-CSF resulted in a decreased dendritic length in neurons traced in the dentate gyrus (mean $\mathrm{G}_{-} \mathrm{CSF}^{-/-}$: 548.57 $\mu \mathrm{m} \pm 140.04$ SEM; mean wild type: $1543.57 \pm 272.85 ; p<0.05$; Student's $t$ test). The morphological analyses of neurons in the CA1 region revealed a significant reduction in the length of apical dendrites accompanied by significantly reduced amounts of branch points ( $p<0.05$; Student's $t$ test). No significant effects were found for the total length of basal dendrites or the amount of nodes in basal dendrites.

\section{Receptor autoradiography}

$\left[{ }^{3} \mathrm{H}\right] \mathrm{MK}-801$ ligand binding

Although no differences in binding density values of $\left[{ }^{3} \mathrm{H}\right] \mathrm{MK}$ -

801 were detectable in primary motor cortex area $\mathrm{M} 1$, in somato- sensory cortex areas S1 and S2 ligand binding to NMDA receptors was generally decreased in $\mathrm{G}-\mathrm{CSF}^{-/-}$mice, although only reaching significance in layers IV and VI of somatosensory cortex S1. $\left[{ }^{3} \mathrm{H}\right] \mathrm{MK}-801$ ligand binding in wild-type and $G-C S F^{-1-}$ mice did not differ in the caudate-putamen. In the hippocampus, a reduction of binding density values was detectable in the dendritic layers of CA1, CA3 and DG, reaching significance in CA3 and DG (Table 1).

\section{$\left[{ }^{3} \mathrm{H}\right]$ Muscimol ligand binding}

In the primary motor cortex M1 no differences in $\left[{ }^{3} \mathrm{H}\right]$ muscimol binding values were present between wild-type and $\mathrm{G}-\mathrm{CSF}^{-/-}$ mice. Similarly, in somatosensory cortex area $S 1$ binding values were largely identical in the superficial layers, whereas slightly enhanced values were seen in deeper layers of G-CSF-deficient mice. In the somatosensory cortex area $\mathrm{S} 2,\left[{ }^{3} \mathrm{H}\right]$ muscimol binding to inhibitory $\mathrm{GABA}_{\mathrm{A}}$ receptors was higher throughout all layers of G-CSF-deficient mice reaching significance in layers II and III. No differences were present in the caudate-putamen. In the hippocampus, ligand binding density values were generally enhanced in dendritic layers of CA1, CA3 and DG, reaching significance in DG (Table 1).

\section{Electrophysiological recordings and long-term potentiation} A conditioning tetanic stimulation was delivered to the CA1 area followed by pulses with stimulation parameters identical to controls. The fEPSP were stable for at least $30 \mathrm{~min}$ before application of tetanic stimulation ( $<10 \%$ variation). Administration of tetanic stimulation by 10 trains of four pulses produced a rapid, stable, and lasting enhancement of the slope of the fEPSP in all tested preparations in wild-type mice ( $n=8,178 \pm 23 \%$ control) (Fig. 6A). A significant reduction in overall LTP induction in G-CSF-deficient mice was observed by induction of LTP by 10 trains of four pulses. G-CSF-deficient mice exhibited impaired tetanusinduced LTP $(n=11,155 \pm 10 \%$ control, Mann-Whitney rank sum test; $p=0.008$ ) (Fig. 6 A). Application of tetanic stimulation by a single $100 \mathrm{~Hz}$ stimulation also produced an enhancement of the slope of the fEPSP in both wild-type ( $n=6,182 \pm 17 \%$ control) and G-CSF-deficient ( $n=6,127 \pm 8 \%$ control) mice. The induction of LTP was significantly inhibited in G-CSF-deficient mice by this method of LTP induction (Mann-Whitney rank sum test; $p<0.001$ ) (Fig. $6 B$ ).

Induction of LTP by four trains of $100 \mathrm{~Hz}$ repeated at intervals of 5 min produced significantly different enhancement of fEPSP in wild-type compared with G-CSF-deficient mice and mice heterozygous for the null mutation (Fig. 6C). This type of LTP induction increased the slope of fEPSP to $245 \pm 19 \%$ control $(n=6)$ in wild-type mice. Both G-CSF-deficient mice and mice heterozygous for the null mutation exhibited significant impaired tetanus induced LTP $(p<0.001)$. G-CSF-deficient mice enhanced LTP to $118 \pm 6 \%$ control $(n=6)$ and mice heterozygous for the null mutation increased slope of fEPSP to $135 \pm 8 \%$ control $(n=6)$.

\section{Discussion}

Our data show that G-CSF deficiency leads to a substantial disruption in spatial learning and memory formation as indicated by the results of the Morris water maze. This finding is confirmed by the results of the object recognition test showing an impaired short- and long-term memory in G-CSF-deficient mice. G-CSF deficiency exerts no alterations in a cued version of the water maze as well as in spontaneous locomotor activity and anxiety- 
related behavior as measured in the open field test and elevated-plus-maze.

In addition to the functional deficits, various structural alterations in the hippocampal formation of G-CSF-deficient mice were detected, which may explain the poorer performance of these animals concerning learning and memory formation. G-CSF deficiency was associated with a reduced ligand binding density of excitatory NMDA receptors in hippocampal subfields CA3 and the dentate gyrus compared with wild-type mice. The central role of this excitatory glutamate receptor for long-term potentiation in the hippocampus, which is suggested to be a basic molecular mechanism for learning and memory, is well known (for review, see Riedel et al., 2003). Consequently, pharmacological blockade of the NMDA receptor has been demonstrated to impair the cognitive performance in a series of experiments (Morris, 1989). A correlation between density of NMDA receptors and learning ability has been shown previously for the NR1 subunit of this receptor (Adams et al., 2001). More importantly, using quantitative ligand binding assays, Stecher and colleagues were able to demonstrate that cognitive abilities of Wistar rats as measured by a passive avoidance learning test strongly corre-

lated with the total density of hippocampal NMDA receptors (Stecher et al., 1997). In the present study, reduced excitation in the hippocampal circuit was further potentiated by an increase of ligand binding densities of the inhibitory $\mathrm{GABA}_{\mathrm{A}}$ receptor resulting in a relative shift in favor of inhibition and impaired behavioral performance. Our results differ from findings by Zilles et al. (2000), who were not able to detect a correlation between NMDA receptor density and behavioral performance in a Morris water test in seven different mouse strains. In their study naive strain means were used for analysis, whereas the present study drew on mean values resulting from individual animals and previous testing. Differences, however, may become visible only when the animals are subjected to the learning procedure.

The present study shows also that G-CSF deficiency leads to a decreased dendritic complexity in hippocampal neurons both in the dentate gyrus and the CA1 region. Structural characteristics such as dendritic arborization, as well as density of dendritic spines, reflect synaptic plasticity. Changes in these characteristics within the hippocampus may be associated with altered learning and memory performance (O'Malley et al., 2000; Pyter et al., 2005). The results obtained in the present study indicate that the presence of G-CSF might be crucial for the maintenance of the anatomical characteristics of hippocampal neurons, which is necessary for an effective memory formation in the brain. Neurotrophic factors such as BDNF have been shown to be essential for the maintenance of striatal neuron dendrite morphology (Gorski et al., 2003; Baquet et al., 2004; Tongiorgi, 2008). The mechanisms underlying G-CSF actions on the maintenance of dendritic complexity are still unknown. Recently, it was demonstrated that activitydependent dendritic arborization requires sequential activation of the NMDAR, CaMKK, CaMKI, and the MEK/ERK pathway (Wayman et al., 2006). In the present study G-CSF deficiency was associated with a reduced ligand binding density of NMDAR, which might contribute to the observed reduction in dendritic complexity.

Along with the reduced ligand binding density of excitatory NMDA receptors revealed by receptor autoradiography and the decreased dendritic complexity, G-CSF-deficient mice exhibited impaired tetanus-induced LTP. Interestingly, mice heterozygous for the null mutation exhibited also impaired tetanus-induced LTP, indicating that a $50 \%$ decrease in G-CSF in heterozygous mice might be sufficient to lead to defective LTP induction. LTP is an experimental phenomenon, which can be used to demonstrate the repertoire of long-lasting modifications of which individual synapses are capable (Malenka and Bear, 2004). LTP is widely considered one of the major cellular mechanisms that underlie learning and memory. It is well established that NMDA receptors are a molecular detector of the coincidence of both the presynaptic release of glutamate and a postsynaptic depolarization at the origin of LTP induction (Sourdet and Debanne, 1999). Presynaptic NMDA receptors have recently been suggested to potentiate the afferent field volley evoked by Schaffer axon stimulation (Suárez et al., 2005). However, other presynaptic mechanisms such as involvement of kainate receptors (Schmitz et al., 2001) or transient outward potassium current could also modify presynaptic excitability (Gu et al., 2004). G-CSF deficiency led to changes of excitability due to upregulation of $\mathrm{GABA}_{\mathrm{A}}$-receptors and downregulation of NMDA-receptors within the hippocampal formation. Along with these changes in excitatory and inhibitory neurotransmitter systems, the observed structural changes likely contribute to the impairment 
Table 1. $\left[{ }^{3} \mathrm{H}\right] \mathrm{MK}-801$ and $\left[{ }^{3} \mathrm{H}\right]$ muscimol binding values in primary motor cortex (M1), somatosensory cortex (S1Tr and S2), caudate putamen, and hippocampus (CA1, CA3, DG) of G-CSF-deficient mice

\begin{tabular}{lcc}
\hline & {$\left[{ }^{3} \mathrm{H}\right] \mathrm{MK}-801$} & {$\left[{ }^{3} \mathrm{H}\right]$ Muscimol } \\
\hline M1 & & \\
Layer I & $104.17 \pm 4.51$ & $102.52 \pm 4.01$ \\
Layer II & $108.03 \pm 3.21$ & $103.23 \pm 3.19$ \\
Layer III & $104.67 \pm 3.27$ & $103.73 \pm 3.46$ \\
Layer IV & $105.61 \pm 3.55$ & $99.50 \pm 4.40$ \\
Layer V & $102.29 \pm 3.45$ & $105.62 \pm 3.02$ \\
Layer VI & $93.35 \pm 2.39$ & $101.11 \pm 3.25$ \\
S1 & & \\
Layer I & $95.14 \pm 4.21$ & $100.55 \pm 2.57$ \\
Layer II & $90.54 \pm 4.17$ & $101.92 \pm 2.91$ \\
Layer III & $91.55 \pm 3.80$ & $105.67 \pm 4.48$ \\
Layer IV & $90.71 \pm 3.14^{*}$ & $118.37 \pm 7.84$ \\
Layer V & $93.64 \pm 2.90$ & $110.23 \pm 3.94$ \\
Layer VI & $86.96 \pm 3.45^{*}$ & $115.65 \pm 9.94$ \\
S2 & & \\
Layer I & $96.59 \pm 6.05$ & $99.84 \pm 6.54$ \\
Layer II & $92.57 \pm 3.06$ & $111.36 \pm 2.99^{*}$ \\
Layer III & $90.46 \pm 2.96$ & $112.26 \pm 3.33^{*}$ \\
Layer IV & $94.29 \pm 2.85$ & $114.00 \pm 5.59$ \\
Layer V & $91.55 \pm 2.44$ & $111.65 \pm 3.17$ \\
Layer VI & $89.08 \pm 3.63$ & $108.84 \pm 3.95$ \\
Caudate putamen & $108.88 \pm 1.64$ & $95.46 \pm 4.66$ \\
CA1 & & \\
Stratum oriens & $93.45 \pm 6.46$ & $115.87 \pm 6.74$ \\
Stratum radiatum & $90.82 \pm 4.02$ & $106.92 \pm 8.74$ \\
Stratum pyramidale & $101.21 \pm 3.80$ & $102.30 \pm 6.41$ \\
CA3 & & $119.38 \pm 6.75$ \\
Stratum oriens & $87.58 \pm 0.92^{*}$ & $105.67 \pm 9.51$ \\
Stratum radiatum & $89.47 \pm 2.74^{*}$ & \\
Stratum pyramidale & $92.92 \pm 3.19$ & \\
DG & & \\
Stratum moleculare & & \\
Stratum granulare & $101.78 \pm 1.01 \pm 4.95$ \\
\hline
\end{tabular}

Values are means \pm SEM $(n=7)$, presented as percentage of wild-type mice.

*Statistically significant difference (ANOVA and Bonferroni error protection; $p<0.05$ ).

of tetanus-induced LTP. G-CSF may participate in activitydependent synaptic plasticity, linking synaptic activity with long-term functional and structural modification of synaptic connections.

Furthermore, our results demonstrate that G-CSF deficiency causes a reduction of BrdU/NeuN-positive and DCX-expressing cells in the dentate gyrus of the hippocampal formation. In the current study, we used DCX and BrdU/NeuN immunohistochemistry to evaluate the adult genesis of hippocampal neurons. DCX is a reliable and specific marker that reflects levels of adult neurogenesis and its modulation (Brown et al., 2003). The expression of DCX starts as neuroblasts are generated and peaks during the second week (Couillard-Despres et al., 2005). To further investigate the effect of G-CSF deficiency on long-term proliferation and to determine the phenotype of the newborn hippocampal cells a BrdU/NeuN imunohistochemistry was performed $6 \mathrm{~d}$ after the last BrdU injection. The findings of the current study confirm and exceed the results of an earlier study showing increased neurogenesis in the dentate gyrus of rats treated with G-CSF (Shyu et al., 2004; Schneider et al., 2005; Kawada et al., 2006). Early in vitro studies have already shown that G-CSF has the ability to induce neuronal differentiation phenotypes in adult stem cells, an effect that correlates to in vivo induction of neurogenesis. Recent studies suggest that adult born neurons may play a crucial role in the formation or consoli-
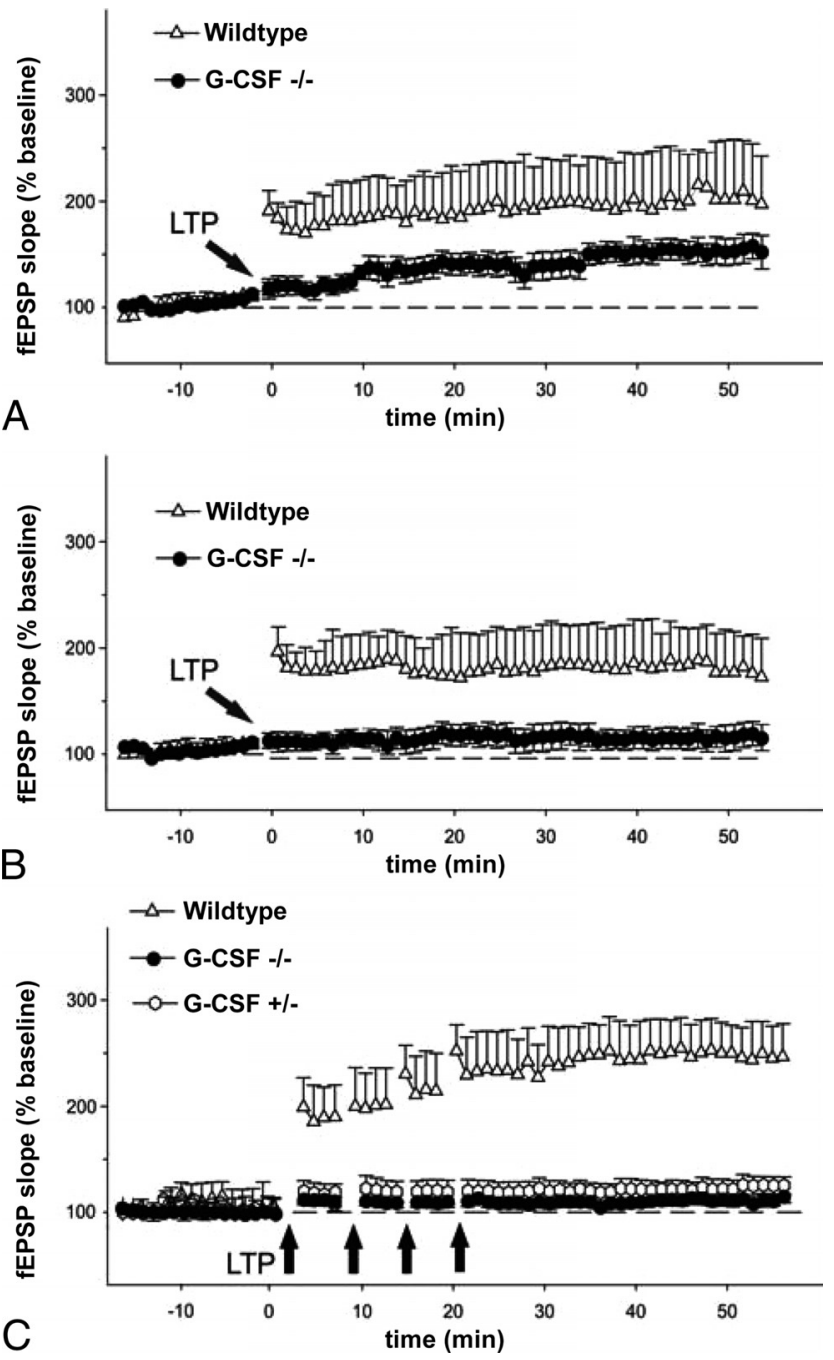

Figure 6. LTP of the fEPSPs in CA1 area of hippocampal tissues of wild-type and G-CSFdeficient mice with different types of tetanic stimulations. Administration of 10 trains of four pulses $(\boldsymbol{A})$, a single $100 \mathrm{~Hz}$ stimulation $(\boldsymbol{B})$, or four trains of $100 \mathrm{~Hz}$ repeated at intervals of $5 \mathrm{~min}$ (C) produced a rapid and stable potentiation in the amplitude of fEPSP, calculated as a percentage of baseline mean response slope. Arrows show the time of tetanic stimulation. The time points given refer to induction of LTP. Note the significant impairment of LTP induction in G-CSF-deficient mice for all different types of LTP induction.

dation of hippocampus-dependent memories (Snyder et al., 2005; Winocur et al., 2006; Dupret et al., 2007; Epp et al., 2007). Although it is still controversial whether adult-born neurons make a distinct contribution to hippocampal functions (Saxe et al., 2006), functional neurogenic action seems to be a prerequisite for effective memory formation. In the present study, the absence of G-CSF results in a reduction in the amount of newborn neurons in the dentate gyrus, which might casually be related to the observed impairment of hippocampus-dependent memory formation.

In addition to the hippocampus sensitive learning and memory tests we performed a motor skill learning test. Motor skill learning is a fundamental adaptive mechanism in human and animal life. Its significance for development, as well as for recovery after brain injury, is increasingly recognized (Buitrago et al., 2004a; Costa et al., 2004; Luft et al., 2004; Flöel et al., 2005; Rösser and Flöel, 2008). Although the motor cortex is arguably the primary motor structure and is essential for performance of skilled movement (Kleim et al., 2002, 2004), motor skill learning has also 
been linked to cerebellar function and to other cortical (Kleim et al., 2007) and striatal (Packard and Knowlton, 2002; Willuhn and Steiner, 2008) influences. Presented data reveal that the presence of G-CSF is vital for the effective formation of motor skill. Numerous studies have demonstrated G-CSF induced improvements of motor functions after experimental ischemia or other neurological diseases. Interestingly, many of these studies used the rotarod to assess basic motor function (Gibson et al., 2005; Park et al., 2005; Schneider et al., 2005, 2006). The rotarod is a practicable and easily quantifiable test, in which animals maintain balance on a rotating rod. Over several days of training rats improve in performance. Buitrago and colleagues demonstrated that rotarod improvement does not solely represent enhanced locomotor ability, but requires the exercise of motor strategies to master the task (Buitrago et al., 2004b). Therefore, the accelerated rotarod training can be regarded as a valid paradigm for motor skill learning. Our data show that G-CSF deficiency causes a severe impairment in the acquisition of motor skill, whereas overall motor function remains intact as revealed by the open field test. Impaired performance in motor learning of G-CSFdeficient mice was associated with reduced ligand binding to NMDA receptors and a simultaneous upregulation of $\left[{ }^{3} \mathrm{H}\right]$ muscimol binding to inhibitory $\mathrm{GABA}_{\mathrm{A}}$ receptors in somatosensory cortical areas. Since the strict division between motor and somatosensory systems even in humans might be less distinct than previously thought (Pleger et al., 2003), this net shift to cortical inhibition may reflect the structural basis of reduced motor learning ability. Moreover, reduced ligand binding to inhibitory $\mathrm{GABA}_{\mathrm{A}}$ receptors in the hippocampus may also play a crucial role for the poorer performance in the skilled motor test. In fact, $\mathrm{GABA}_{\mathrm{A}}$ receptor binding density has recently been shown to negatively correlate with activity-dependent scores resulting from the swimming speed in a water maze test (Zilles et al., 2000). The enhancement of motor function after G-CSF treatment as seen in earlier studies might be the result of enhanced motor skill learning and thereby exceeding growth factor enhanced recovery processes.

Overall, our results confirm G-CSF as an essential neurotrophic factor and point to a possible role for G-CSF in proliferation and differentiation of neural cells, necessary for the structural and functional integrity of brain areas like the hippocampal formation.

\section{References}

Adams MM, Smith TD, Moga D, Gallagher M, Wang Y, Wolfe BB, Rapp PR, Morrison JH (2001) Hippocampal dependent learning ability correlates with $N$-methyl-D-aspartate (NMDA) receptor levels in CA3 neurons of young and aged rats. J Comp Neurol 432:230-243.

Baquet ZC, Gorski JA, Jones KR (2004) Early striatal dendrite deficits followed by neuron loss with advanced age in the absence of anterograde cortical brain-derived neurotrophic factor. J Neurosci 24:4250-4258.

Brown JP, Couillard-Després S, Cooper-Kuhn CM, Winkler J, Aigner L, Kuhn HG (2003) Transient expression of doublecortin during adult neurogenesis. J Comp Neurol 467:1-10.

Buitrago MM, Ringer T, Schulz JB, Dichgans J, Luft AR (2004a) Characterization of motor skill and instrumental learning time scales in a skilled reaching task in rat. Behav Brain Res 155:249-256.

Buitrago MM, Schulz JB, Dichgans J, Luft AR (2004b) Short and long-term motor skill learning in an accelerated rotarod training paradigm. Neurobiol Learn Mem 81:211-216.

Cao XQ, Arai H, Ren YR, Oizumi H, Zhang N, Seike S, Furuya T, Yasuda T, Mizuno Y, Mochizuki H (2006) Recombinant human granulocyte colony-stimulating factor protects against MPTP-induced dopaminergic cell death in mice by altering Bcl-2/Bax expression levels. J Neurochem 99:861-867.

Costa RM, Cohen D, Nicolelis MA (2004) Differential corticostriatal plas- ticity during fast and slow motor skill learning in mice. Curr Biol 14:1124-1134.

Couillard-Despres S, Winner B, Schaubeck S, Aigner R, Vroemen M, Weidner N, Bogdahn U, Winkler J, Kuhn HG, Aigner L (2005) Doublecortin expression levels in adult brain reflect neurogenesis. Eur J Neurosci 21:1-14.

Dupret D, Fabre A, Döbrössy MD, Panatier A, Rodríguez JJ, Lamarque S, Lemaire V, Oliet SH, Piazza PV, Abrous DN (2007) Spatial learning depends on both the addition and removal of new hippocampal neurons. PLoS Biol 5:e214.

Eadie BD, Redila VA, Christie BR (2005) Voluntary exercise alters the cytoarchitecture of the adult dentate gyrus by increasing cellular proliferation, dendritic complexity, and spine density. J Comp Neurol 486:39-47.

Epp JR, Spritzer MD, Galea LA (2007) Hippocampus-dependent learning promotes survival of new neurons in the dentate gyrus at a specific time during cell maturation. Neuroscience 149:273-285.

Flöel A, Breitenstein C, Hummel F, Celnik P, Gingert C, Sawaki L, Knecht S, Cohen LG (2005) Dopaminergic influences on formation of a motor memory. Ann Neurol 58:121-130.

Gibb R, Kolb B (1998) A method for vibratome sectioning of Golgi-Cox stained whole rat brain. J Neurosci Methods 79:1-4.

Gibson CL, Bath PM, Murphy SP (2005) G-CSF reduces infarct volume and improves functional outcome after transient focal cerebral ischemia in mice. J Cereb Blood Flow Metab 25:431-439.

Gorski JA, Zeiler SR, Tamowski S, Jones KR (2003) Brain-derived neurotrophic factor is required for the maintenance of cortical dendrites. J Neurosci 23:6856-6865.

Gu Y, Ge SY, Ruan DY (2004) Effect of 4-aminopyridine on synaptic transmission in rat hippocampal slices. Brain Res 1006:225-232.

Kawada H, Takizawa S, Takanashi T, Morita Y, Fujita J, Fukuda K, Takagi S, Okano H, Ando K, Hotta T (2006) Administration of hematopoietic cytokines in the subacute phase after cerebral infarction is effective for functional recovery facilitating proliferation of intrinsic neural stem/progenitor cells and transition of bone marrow-derived neuronal cells. Circulation 113:701-710.

Kleim JA, Barbay S, Cooper NR, Hogg TM, Reidel CN, Remple MS, Nudo RJ (2002) Motor learning-dependent synaptogenesis is localized to functionally reorganized motor cortex. Neurobiol Learn Mem 77:63-77.

Kleim JA, Hogg TM, VandenBerg PM, Cooper NR, Bruneau R, Remple M (2004) Cortical synaptogenesis and motor map reorganization occur during late, but not early, phase of motor skill learning. J Neurosci 24:628-633.

Kleim JA, Markham JA, Vij K, Freese JL, Ballard DH, Greenough WT (2007) Motor learning induces astrocytic hypertrophy in the cerebellar cortex. Behav Brain Res 178:244-249.

Komine-Kobayashi M, Zhang N, Liu M, Tanaka R, Hara H, Osaka A, Mochizuki H, Mizuno Y, Urabe T (2006) Neuroprotective effect of recombinant human granulocyte colony-stimulating factor in transient focal ischemia of mice. J Cereb Blood Flow Metab 26:402-413.

Lieschke GJ, Grail D, Hodgson G, Metcalf D, Stanley E, Cheers C, Fowler KJ, Basu S, Zhan YF, Dunn AR (1994) Mice lacking granulocyte colonystimulating factor have chronic neutropenia, granulocyte and macrophage progenitor cell deficiency, and impaired neutrophil mobilization. Blood 84:1737-1746.

Luft AR, Buitrago MM, Ringer T, Dichgans J, Schulz JB (2004) Motor skill learning depends on protein synthesis in motor cortex after training. J Neurosci 24:6515-6520.

Malenka RC, Bear MF (2004) LTP and LTD: an embarrassment of riches. Neuron 44:5-21.

Meuer K, Pitzer C, Teismann P, Krüger C, Göricke B, Laage R, Lingor P, Peters K, Schlachetzki JC, Kobayashi K, Dietz GP, Weber D, Ferger B, Schäbitz WR, Bach A, Schulz JB, Bähr M, Schneider A, Weishaupt JH (2006) Granulocyte-colony stimulating factor is neuroprotective in a model of Parkinson's disease. J Neurochem 97:675-686.

Minnerup J, Heidrich J, Wellmann J, Rogalewski A, Schneider A, Schäbitz WR (2008) Meta-analysis of the efficacy of granulocyte-colony stimulating factor in animal models of focal cerebral ischemia. Stroke 39:1855-1861.

Morris RG (1989) Synaptic plasticity and learning: selective impairment of learning rats and blockade of long-term potentiation in vivo by the $\mathrm{N}$-methyl-D-aspartate receptor antagonist AP5. J Neurosci 9:3040-3057.

O'Malley A, O'Connell C, Murphy KJ, Regan CM (2000) Transient spine density increases in the mid-molecular layer of hippocampal dentate gy- 
rus accompany consolidation of a spatial learning task in the rodent. Neuroscience 99:229-232.

Packard MG, Knowlton BJ (2002) Learning and memory functions of the basal ganglia. Annu Rev Neurosci 25:563-593.

Park HK, Chu K, Lee ST, Jung KH, Kim EH, Lee KB, Song YM, Jeong SW, Kim M, Roh JK (2005) Granulocyte colony-stimulating factor induces sensorimotor recovery in intracerebral hemorrhage. Brain Res 1041:125-131.

Pleger B, Schwenkreis P, Dinse HR, Ragert P, Höffken O, Malin JP, Tegenthoff M (2003) Pharmacological suppression of plastic changes in human primary somatosensory cortex after motor learning. Exp Brain Res 148:525-532.

Pyter LM, Reader BF, Nelson RJ (2005) Short photoperiods impair spatial learning and alter hippocampal dendritic morphology in adult male white-footed mice (Peromyscus leucopus). J Neurosci 25:4521-4526.

Riedel G, Platt B, Micheau J (2003) Glutamate receptor function in learning and memory. Behav Brain Res 140:1-47.

Rösser N, Flöel A (2008) Pharmacological enhancement of motor recovery in subacute and chronic stroke. NeuroRehabilitation 23:95-103.

Saxe MD, Battaglia F, Wang JW, Malleret G, David DJ, Monckton JE, Garcia AD, Sofroniew MV, Kandel ER, Santarelli L, Hen R, Drew MR (2006) Ablation of hippocampal neurogenesis impairs contextual fear conditioning and synaptic plasticity in the dentate gyrus. Proc Natl Acad Sci U S A 103:17501-17506.

Schäbitz WR, Schneider A (2007) New targets for established proteins: exploring G-CSF for the treatment of stroke. Trends Pharmacol Sci 28:157-161.

Schäbitz WR, Kollmar R, Schwaninger M, Juettler E, Bardutzky J, Schölzke MN, Sommer C, Schwab S (2003) Neuroprotective effect of granulocyte colonystimulating factor after focal cerebral ischemia. Stroke 34:745-751.

Schmitz D, Mellor J, Nicoll RA (2001) Presynaptic kainate receptor mediation of frequency facilitation at hippocampal mossy fiber synapses. Science 291:1972-1976.

Schneider A, Krüger C, Steigleder T, Weber D, Pitzer C, Laage R, Aronowski J, Maurer MH, Gassler N, Mier W, Hasselblatt M, Kollmar R, Schwab S, Sommer C, Bach A, Kuhn HG, Schäbitz WR (2005) The hematopoietic factor G-CSF is a neuronal ligand that counteracts programmed cell death and drives neurogenesis. J Clin Invest 115:2083-2098.

Schneider A, Wysocki R, Pitzer C, Krüger C, Laage R, Schwab S, Bach A, Schäbitz WR (2006) An extended window of opportunity for G-CSF treatment in cerebral ischemia. BMC Biol 4:36.

Schomacher M, Müller HD, Sommer C (2006) Short-term ischemia usually used for ischemic preconditioning down-regulates central cannabinoid receptors in the gerbil hippocampus. Acta Neuropathol 111:8-14.

Shyu WC, Lin SZ, Yang HI, Tzeng YS, Pang CY, Yen PS, Li H (2004) Functional recovery of stroke rats induced by granulocyte colony-stimulating factor-stimulated stem cells. Circulation 110:1847-1854.

Snyder JS, Hong NS, McDonald RJ, Wojtowicz JM (2005) A role for adult neurogenesis in spatial long-term memory. Neuroscience 130:843-852.

Solaroglu I, Tsubokawa T, Cahill J, Zhang JH (2006) Anti-apoptotic effect of granulocyte-colony stimulating factor after focal cerebral ischemia in the rat. Neuroscience 143:965-974.

Solaroglu I, Jadhav V, Zhang JH (2007) Neuroprotective effect of granulocytecolony stimulating factor. Front Biosci 12:712-724.

Sourdet V, Debanne D (1999) The role of dendritic filtering in associative long-term synaptic plasticity. Learn Mem 6:422-447.

Stecher J, Müller WE, Hoyer S (1997) Learning abilities depend on NMDAreceptor density in hippocampus in adult rats. J Neural Transm 104:281-289.

Suárez LM, Suárez F, Del Olmo N, Ruiz M, González-Escalada JR, Solís JM (2005) Presynaptic NMDA autoreceptors facilitate axon excitability: a new molecular target for the anticonvulsant gabapentin. Eur J Neurosci 21:197-209.

Tongiorgi E (2008) Activity-dependent expression of brain-derived neurotrophic factor in dendrites: facts and open questions. Neurosci Res 61:335-346.

Tsai KJ, Tsai YC, Shen CK (2007) G-CSF rescues the memory impairment of animal models of Alzheimer's disease. J Exp Med 204:1273-1280.

Wayman GA, Impey S, Marks D, Saneyoshi T, Grant WF, Derkach V, Soderling TR (2006) Activity-dependent dendritic arborization mediated by CaMkinase I activation and enhanced CREB-dependent transcription of Wnt-2. Neuron 50:897-909.

Willuhn I, Steiner H (2008) Motor-skill learning in a novel running-wheel task is dependent on D1 dopamine receptors in the striatum. Neuroscience 153:249-258.

Winocur G, Wojtowicz JM, Sekeres M, Snyder JS, Wang S (2006) Inhibition of neurogenesis interferes with hippocampus-dependent memory function. Hippocampus 16:296-304.

Zilles K, Wu J, Crusio WE, Schwegler H (2000) Water maze and radial maze learning and the density of binding sites of glutamate, GABA, and serotonin receptors in the hippocampus of inbred mouse strains. Hippocampus 10: 213-225. 